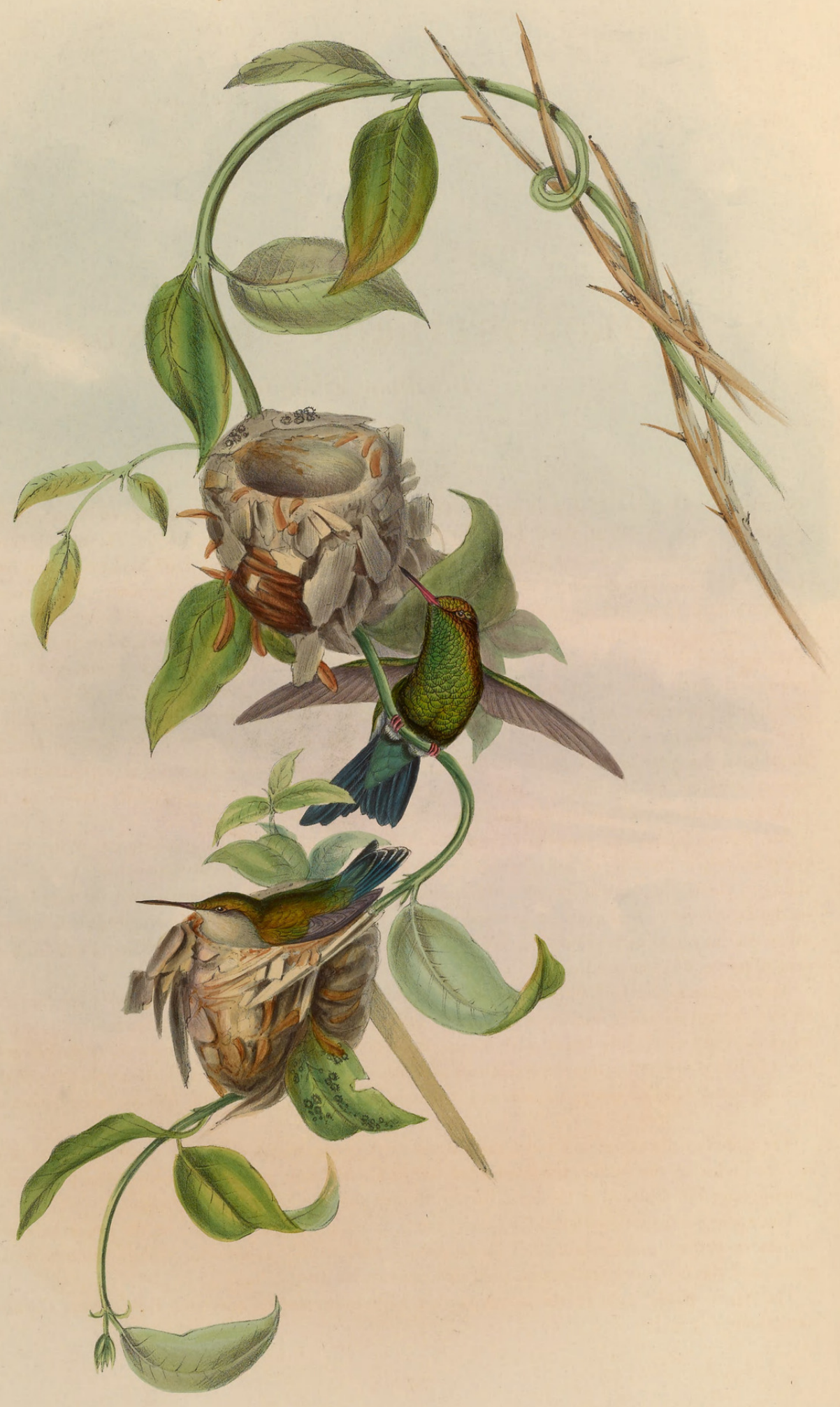

I'HLDRDSTILBDNA PRASTIS 


\title{
CHLOROSTILBON PRASINUS.
}

\author{
Brazilian Emerald.
}

No state of confusion can be greater than that which exists respecting the small green Humming Birds, and particularly as to which of them the terms prasinus and atala especially belong. The two birds commonly known by those names do not agree with the figures of the birds so called by M. Lesson, and indeed it is impossible to determine with certainty what birds he intended they should represent; I therefore propose to retain those names for the birds generally known among collectors by these appellations.

The true habitat of the bird here represented is the eastern part of Brazil, over which it ranges from the river Amazon to the latitude of Rio de Janeiro, in which latter province it is very abundant. I have in my possession three very different, apparently local, varieties of this bird; but as the difference consists in the tint of the colour alone, and not in their size or structure, I cannot regard them as specifically distinct. The specimens from the neighbourhood of the city of Rio de Janeiro are wholly metallic bluish green; those from the hilly parts of Minas Geraes have the head and sides of the neck of a golden lustre; while one sent to me by Mr. Reeves, and said to have been procured at Para, has the crown of the head, back and abdomen reddish bronze, the throat alone being green.

Mr. Reeves informs me that the Chlorostilbon prasinus remains in the neighbourhood of Rio the whole of the year, and is drest in its full plumage during the months of August and September; he also states that the open plains, the densest forests and the sides of rivers are alike resorted to ; that the nest is suspended on reeds and ferns, and even on grasses; two or three being frequently placed within a few feet of each other, and in some instances two on the same branch, as figured in the accompanying Plate from examples sent to me by this gentleman.

Accompanying the brilliantly coloured birds which we know to be males, examples are frequently sent having the entire under surface of a uniform greyish brown, without any metallic brilliancy, and with the outer tail-feathers slightly tipped with white; these dull-coloured birds I have always regarded as females; but it is just possible that this sex sometimes assumes, especially in old age, the brilliant plumage of the male; this, however, is by no means certain, and it remains to be seen whether this opinion be or be not correct.

The male has the upper and under surface yellowish green, with a golden lustre on the crown of the head and the sides of the neck; wings purplish brown; tail black, glossed with steel-blue; throat brilliant grass-green; bill flesh-red at the base, darker towards the tip; feet reddish brown.

The upper surface of the female is bronzy green, passing into purer green on the upper tail-coverts; all the under surface greyish buff; tail black, glossed with steel-blue, the four middle feathers washed with green, and the two outer feathers on each side tipped with greyish buff.

The figure of the male in the accompanying Plate represents-a specimen from Minas Geraes, of the natural size. 


\section{$2 \mathrm{BHL}$ Biodiversity Heritage Library}

Gould, John. 1861. "Chlorostilbon prasinus, Brazilian Emerald. [PI. 355]." A monograph of the Trochilidae, or family of humming-birds 5, https://doi.org/10.5962/p.317164.

View This Item Online: https://www.biodiversitylibrary.org/item/108806

DOI: https://doi.org/10.5962/p.317164

Permalink: https://www.biodiversitylibrary.org/partpdf/317164

\section{Holding Institution}

Smithsonian Libraries

\section{Sponsored by}

Smithsonian Institution Libraries

\section{Copyright \& Reuse}

Copyright Status: NOT_IN_COPYRIGHT

This document was created from content at the Biodiversity Heritage Library, the world's largest open access digital library for biodiversity literature and archives. Visit BHL at https://www.biodiversitylibrary.org. 